\title{
On Fire This Time
}

\author{
JOHN BELLAMY FOSTER
}

We are seeing today what appear to be the beginnings of an ecological revolution, a new historical moment unlike any humanity has experienced. ${ }^{1}$ As Naomi Klein suggests in her new book On Fire, not only is the planet burning, but a revolutionary climate movement is rising up and is now on fire in response. ${ }^{2}$ Here is a brief chronology of the last year, focusing on climate actions in Europe and North America - though it should be stressed that the whole world is now objectively (and subjectively) on fire this time ${ }^{3}$ :

- August 2018: 15-year-old Greta Thunberg begins her school strike outside the Swedish Parliament.

- October 8, 2018: The United Nations Intergovernmental Panel on Climate Change (IPCC) releases Special Report on Global Warming of $1.5^{\circ} \mathrm{C}$ pointing to the need for "systems transitions...unprecedented in terms of scale."4

- October 17, 2018: Extinction Rebellion activists occupy UK Greenpeace headquarters demanding the staging of mass civil disobedience to address the climate emergency.

- November 6, 2018: Alexandria Ocasio-Cortez (Democrat) is elected as a Congressional Representative on a platform that includes a Green New Deal. ${ }^{5}$

- November 13, 2018: Members of the Sunrise Movement occupy House Speaker Nancy Pelosi's Congressional office; newly elected Representative Ocasio-Cortez joins them.

- November 17, 2018: Extinction Rebellion activists block five bridges over the Thames in London.

- December 10, 2018: Sunrise Movement activists flood key Democratic Party Congressional offices demanding the creation of a Select Committee for a Green New Deal.

- December 19, 2018: Members of Congress in support of a Select Committee for a Green New Deal rises to forty.

- January 25, 2019: Thunberg tells World Economic Forum: "Our house is on fire.... I want you to act as if our house is on fire. Because it is."

- February 7, 2019: Representative Ocasio-Cortez and Senator Edward Markey introduce the Green New Deal Resolution in Congress. ${ }^{7}$

- March 15, 2019: Nearly 2,100 youth-led climate strikes occur in 125 countries with 1.6 million participating (100,000 in Milan, 40,000 in Paris, 150,000 in Montreal). ${ }^{8}$

- April 15-19, 2019: Extinction Rebellion shuts down large parts of central London.

- April 23, 2019: Speaking to both Houses of Parliament, Thunberg states: "Did you hear what I just said? Is my English okay? Is the microphone on? Because I am beginning to wonder." 
- April 25, 2019: Extinction Rebellion protesters blockade the London Stock Exchange, gluing themselves across its entrances.

- May 1, 2019: UK Parliament declares a Climate Emergency shortly after similar declarations by Scotland and Wales.

- August 22, 2019: Senator and presidential candidate Bernie Sanders unveils the most comprehensive Green New Deal plan to date, proposing a public investment of $\$ 16.3$ trillion over ten years. ${ }^{10}$

- September 12, 2019: The number of Congressional cosponsors of the Green New Deal Resolution reaches 107. ${ }^{11}$

- September 20, 2019: Four million people join the global climate strike, staging more than 2,500 events in 150 countries. 1.4 million protest in Germany alone. ${ }^{12}$

- September 23, 2019: Thunberg tells the United Nations: "People are suffering. People are dying. Entire ecosystems are collapsing. We are in the beginning of a mass extinction, and all you can talk about is money and fairy tales of eternal economic growth. How dare you!"13

- September 25, 2019: IPCC Special Report on the Ocean and Cryosphere is released, indicating that many low-lying megacities and small islands, especially in tropical regions, will experience "extreme sea level events" every year by $2050 .{ }^{14}$

The outpouring of climate change protests over the last year were largely in response to the IPCC's October 2018 report, which declares that carbon dioxide emissions need to peak in 2020, drop by 45 percent by 2030, and reach zero net emissions by 2050 for the world to have a reasonable chance of avoiding a catastrophic $1.5^{\circ} \mathrm{C}$ increase in global average temperature. ${ }^{15}$ Untold numbers of people have suddenly become aware that, in order to pull back from the edge of the cliff, it is necessary to initiate socioeconomic change on a scale commensurate with that of the Earth System crisis that humanity is facing. This has resulted in System Change Not Climate Change, the name of the leading U.S. ecosocialist movement, becoming the mantra of the entire global grassroots climate movement. ${ }^{16}$

The meteoric rise of Thunberg and the student climate strike movement, the Sunrise Movement, Extinction Rebellion, and the Green New Deal, all within the brief span of a year, coupled with the actual protests and strikes of millions of climate change activists, the vast majority of them young, has meant a massive transformation of the environmental struggle in the advanced capitalist states. Virtually overnight, the struggle has shifted from its previous more generic climate action framework toward the more radical climate justice and ecosocialist wings of the movement. ${ }^{17}$ The climate action movement has been largely reformist, merely seeking to nudge business-as-usual in a climate-conscious direction. The 400,000-person climate march in New York in 2014, organized 
by the People's Climate Movement, proceeded to 34th Street and 11th Avenue, a nondestination, rather than to the United Nations where climate negotiators were meeting, with the result that it had more the character of a parade than a protest. ${ }^{18}$

In contrast, climate justice organizations such as Extinction Rebellion, the Sunrise Movement, and the Climate Justice Alliance are known for their direct action. The new movement is younger, bolder, more diverse, and more revolutionary in its outlook. ${ }^{19}$ In the present struggle for the planet, there is a growing recognition that the social and ecological relations of production must be transformed. Only a transformation that is revolutionary in terms of scale and tempo can pull humanity out of the trap that capitalism has imposed. As Thunberg told the UN Climate Change Conference on December 15, 2018, "If the solutions within this system are so impossible to find then maybe we should change the system itself." ${ }^{20}$

\section{The Green New Deal: Reform or Revolution?}

What has made the struggle for an ecological revolution a seemingly unstoppable force in the last year is the rise of the Green New Deal, or a program that represents the coalescence of the movement to arrest climate change with the struggle for economic and social justice, focusing on the effects on workers and frontline communities. However, the Green New Deal was not originally a radical-transformational strategy, but rather a moderate-reformist one. The phrase Green New Deal took hold in 2007 in a meeting between Colin Hines, former head of Greenpeace's International Economics unit, and Guardian economics editor Larry Elliott. Faced with growing economic and environmental problems, Hines suggested a dose of Green Keynesian spending, labeling it a Green New Deal after Franklin Roosevelt's New Deal during the Great Depression in the United States. Elliott, Hines, and others, including British entrepreneur Jeremy Leggett, launched the UK Green New Deal Group later that year. ${ }^{21}$

The idea caught on quickly within environmental policy circles. Procorporate New York Times columnist Thomas Friedman began promoting the term in the United States at about the same time as a new capitalist ecomodernist strategy. ${ }^{22}$ Barack Obama was to advance a Green New Deal proposal in his 2008 campaign. However, he dropped the Green New Deal terminology along with what remained of its substance after the midterm elections in 2010. ${ }^{23}$ In September 2009, the UN Environment Programme issued a report entitled Global Green New Deal, consisting of a sustainable growth plan. ${ }^{24}$ That same month, the Green European Foundation published A Green New Deal for Europe, a Keynesian green capitalist strategy, today known as the European Green New Deal. ${ }^{25}$ 
All of these proposals, introduced under the mantle of a Green New Deal, were top-down combinations of Green Keynesianism, ecomodernism, and corporatist technocratic planning incorporating a marginal concern for promoting employment and eradicating poverty, while standing for a mildly reformist green capitalism. In this respect, the first Green New Deal proposals had more in common with Franklin Roosevelt's First New Deal, from 1933 to 1935 in the United States, which was corporatist and heavily probusiness in character, than with the Second New Deal from 1935 to 1940, which was animated by the great revolt of industrial labor in the mid-late 1930s. ${ }^{26}$

In sharp contrast to these early corporatist proposals, the radical version of the Green New Deal that has gained traction in the last year in the United States has its historical inspiration in the great revolt from below in the Second New Deal. A key force in this metamorphosis was the Climate Justice Alliance that arose in 2013 through the coalescence of various primarily environmental justice organizations. The Climate Justice Alliance currently unites sixty-eight different frontline organizations, representing low-income communities and communities of color, engaged in immediate struggles for environmental justice and supporting a just transition. ${ }^{27}$

The critical concept of a just transition had its origins in the 1980s, in the efforts of ecosocialist Tony Mazzocchi of the Oil, Chemical and Atomic Workers Union to build a radical labor-environmental justice movement and was later promoted by the United Steel Workers. ${ }^{28}$ Directed at overcoming the chasm between economic and ecological struggles, a just transition is now recognized as the main principle, beyond the safeguarding of the climate itself, in the struggle for a peoples' Green New Deal.

The Green New Deal first metamorphosed into a radical grassroots strategy - or a Peoples' Green New Deal in the terms of Science for the Peopleduring Jill Stein's two successive Green Party presidential campaigns in 2012 and 2016. ${ }^{29}$ The Green Party's Green New Deal had four pillars: (1) An Economic Bill of Rights, including the right to employment, workers' rights, the right to health care (Medicare for All), and the right to tuition-free, federally funded, higher education; (2) a Green Transition, promoting investment in small businesses, green research, and green jobs; (3) Real Financial Reform, including relieving homeowner and student debt, democratizing monetary policy, breaking up financial corporations, ending government bailouts of banks, and regulating financial derivatives; and (4) a Functioning Democracy, revoking corporate personhood, incorporating a Voter's Bill of Rights, repealing the Patriot Act, and cutting military spending by 50 percent. ${ }^{30}$

There can be no doubt about the radical (and anti-imperialist) nature of the Green Party's original Green New Deal platform. Its designated halving of U.S. military spending was the key to its plan to increase 
federal spending in other spheres. At the heart of the Green Party's Green New Deal was thus an attack on the economic, financial, and military structure of the U.S. empire, while focusing its economic policy proposals on a Green Transition that would provide up to twenty million new green jobs. ${ }^{31}$ The Green Transition part of the program was, ironically, the weakest component of the Green Party's Green New Deal. The innovation of the Green Party, however, was to link vital environmental change to what it conceived as equally necessary social change.

But it was not until the radical Green New Deal burst forth in Congress in November 2018, spearheaded by the newly elected Congressional Representative Ocasio-Cortez following the midterm U.S. elections, that it suddenly became a major factor in the U.S. political landscape. Ocasio-Cortez had decided to run for office after joining the hard-fought indigenous-led protest aimed at blocking the Dakota Access Pipeline at Standing Rock in North Dakota in 2016-17. In campaigning in New York's 14th Congressional District (representing the Bronx and part of north-central Queens), she signed the Sunrise Movement's No Fossil Fuel Money pledge, with the result that the Sunrise Movement canvassed for her, contributing to her surprise election victory against ten-term-incumbent Representative Joe Crowley. ${ }^{32}$ The Sunrise Movement's sit-in in Pelosi's office in support of a Green New Deal a week after the midterm elections was immediately joined by Ocasio-Cortez, who, together with Markey, was to introduce the Green New Deal Resolution in Congress.

Ocasio-Cortez's campaign drew much of its inspiration from Sanders' self-described democratic socialist campaign for president in 2016 that led to the revival of the Democratic Socialists of America (DSA), which Ocasio-Cortez joined prior to her election. From the start, the people's Green New Deal resolution thus took on what was in many ways an ecosocialist character. ${ }^{33}$

In the fourteen-page Green New Deal Resolution presented by OcasioCortez and Markey in February 2019, the reality of the climate emergency is laid out along with the extent of U.S. responsibility. This is juxtaposed to "related crises" manifested in: the decline in life expectancy, wage stagnation, diminishing class mobility, soaring inequality, the racial divide in wealth, and the gender earnings gap. The solution offered is a Green New Deal that would achieve net-zero greenhouse gas emissions through a "just transition," creating "millions of good, high wage jobs" in the process of securing a sustainable environment. It is designed to "promote justice and equity by stopping current, preventing future, and repairing historic oppression of indigenous peoples, communities of color, migrant communities, deindustrialized communities, depopulated 
rural communities, the poor, low income workers, women, the elderly, the unhoused, people with disabilities, and youth (referred to in this resolution as 'frontline and vulnerable communities')."

The Green New Deal Resolution is based on a "10-year national mobilization." In this period, the goal is to achieve " 100 percent of the power demand in the United States through clean, renewable, and zero-emission energy sources." Other measures include opposing "domestic or international monopolies"; supporting family farming; building a sustainable food system; establishing a zero-emission vehicle infrastructure; promoting public transit; investing in high-speed rail; ensuring the international exchange of climate-related technology; creating partnerships with frontline communities, labor unions, and worker cooperatives; providing job guarantees, training, and higher education to the working population; ensuring high-quality, universal health care for the entire U.S. population; and protecting public lands and waters. ${ }^{34}$

Unlike the Green Party's New Deal, the Democratic Party's Green New Deal Resolution as introduced by Ocasio-Cortez and Markey does not directly oppose financial capital or U.S. spending on the military and empire. Rather, its radical character is confined to linking a massive mobilization to combat climate change to a just transition for frontline communities, including redistributive economic measures. And yet there is no doubt about the radical nature of the demands put forward, which if carried out fully would require a mass mobilization of the entire society aimed at a vast transformation of U.S. capital and the expropriation of the fossil fuel industry.

Sanders' thirty-four-page Green New Deal plan goes still further ${ }^{35}$ It requires 100 percent renewable energy for electricity and transportation by 2030 (amounting to a 71 percent reduction in U.S. carbon emissions) and complete decarbonization by 2050 at the latest. It sets out to accomplish all of this by devoting $\$ 16.3$ trillion in public investment to the massive mobilization of resources to displace fossil fuels; insisting on a just transition for both workers and frontline communities; declaring a climate change national emergency; reauthorizing the Civilian Conservation Corps of the New Deal; and banning offshore drilling, fracking, and mountaintop removal coal mining. It would offer $\$ 200$ billion to the Green Climate Fund to support necessary transformations in poor countries with the aim of helping reduce carbon emissions in less industrialized nations by 36 percent by 2030 .

To ensure a just transition for workers, Sanders proposes "up to five years of a wage guarantee, job placement assistance, relocation assistance, health care, and a pension based on their previous salary," along 
with housing assistance, to all workers displaced due to the switch away from fossil fuels. Workers will receive training for different career paths, including fully paid four-year college education. Health care cost would be covered by Medicare for All. The principles of environmental justice will be adhered to in order to protect frontline communities. Funding will be provided to impacted frontline communities, including the indigenous. Tribal sovereignty will be respected, with the Sanders plan including $\$ 1.12$ billion offered for tribal land access and extension programs. In addition, the government "will set aside $\$ 41$ billion to help large confined animal feeding operations" convert to "ecologically regenerative practices," to be coupled with support to family farms.

Funding would come from a number of sources including: (1) "massively raising taxes on corporate polluters' and investors' fossil fuel income and wealth" as well as "raising penalties on pollution from fossil fuel energy generation" by corporations; (2) eliminating subsidies to the fossil fuel industry; (3) "generating revenue from the wholesale of energy produced by regional Power Marketing Authorities" - with the added revenue being used to support the Green New Deal to be collected until 2035, after which electricity would be provided virtually free to customers aside from operations and maintenance costs; (4) cutting back on military spending directed at safeguarding global oil supplies; (5) collecting additional tax revenue resulting from the increase in employment; and (6) making corporations and the wealthy pay their "fair share." ${ }^{36}$

Sanders's Green New Deal is thus distinguished from Ocasio-Cortez and Markey's House Resolution in: (1) setting a definite timeline for greenhouse gas emission cuts (one far more ambitious for the United States, due to its unique responsibilities, than what is required by the world on average under the global carbon budget); (2) its direct confrontation with fossil capital; (3) explicitly basing its just transition on the needs of the working class as a whole, while focusing in particular on frontline communities; (4) specifying, like the earlier Green Party New Deal proposal, the creation of twenty million new jobs; (4) banning offshore drilling, fracking, and mountaintop removal coal mining; (5) confronting the role of the military in safeguarding the global fossil fuel economy; (6) stipulating $\$ 16.3$ trillion in federal government expenditures on the Green New Deal over ten years; and (7) relying on taxes on polluting corporations to help fund the Green New Deal itself. ${ }^{37}$ The Sanders plan, however, backs off from the Green Party's bold proposal to halve military spending.

The peoples' Green New Deal strategies now being advanced constitute what in socialist theory is called revolutionary reforms, that is, reforms that promise a fundamental restructuring of economic, political, and ecological 
power, and that point toward rather than away from the transition from capitalism to socialism. The scale of the changes envisaged are far greater, representing a more formidable threat to the power of capital, than those posed by the Second New Deal of the late 1930s. The complete disinvestment in fossil fuels, including fossil fuel reserves, constitutes a kind of abolitionism driven by sheer necessity that finds its closest analogy, in terms of its overall economic-scale effects, in the abolition of slavery in the United States. It has been estimated that in 1860 , slaves constituted "the largest single financial asset in the entire U.S. economy, worth more than all manufacturing and railroads combined." ${ }^{38}$ Today, taking on the fossil fuel industry and related industries and infrastructure, including the entire financial structure, raises analogous conflicts over wealth and power in terms of the sheer scale involved, and is only conceivable as part of a general ecological and social transformation. Thus, the Inter-American Development Bank declared in 2016 that the energy companies were facing the potential loss of \$28 trillion as a result of the world's need to keep fossil fuels in the ground. ${ }^{39}$

As capital understood from the start, these changes would threaten the entire political-economic order, since once the population was mobilized for change, the entire metabolism of capitalist production would be challenged. ${ }^{40}$ Energy corporations, Klein writes, will "have to leave trillions of dollars' worth of proven fossil fuel reserves [which they count as assets] in the ground." ${ }^{41}$ For the climate justice movement to take on fossil capital and the reigning capitalist system as a whole in this way requires social mobilization and class struggle on an enormous scale, with the major transformations in production-energy to be introduced in a mere handful of years.

To be sure, none of the Green New Deal proposals are anywhere near to conceiving, much less tackling, the immensity of the task that the current planetary emergency demands. But they are sufficiently grounded in necessity that they could spark a global revolutionary struggle for freedom and sustainability, since the changes contemplated go against the logic of capital itself and cannot be achieved without a mobilization of the population as a whole on an emergency basis.

Still, there are lingering contradictions to the radical Green New Deal strategies themselves, related to their emphasis on economic growth and capital accumulation. The constraints imposed by the need to stabilize the climate are severe, requiring changes in the underlying structure of production. Nevertheless, all of the current Green New Deal proposals largely eschew any mention of direct conservation of resources or cuts in overall consumption - much less emergency measures like rationing as an equitable non-price-related means of reallocating society's scarce resources (a fairly popular measure in the United States in the Second World War) ${ }^{42}$ 
None consider the full level of waste built into the current accumulation system and how that could be turned to ecological advantage. Instead, all of the plans are based on the notion of promoting rapid, exponential economic growth or capital accumulation - despite the fact that this would compound the planetary emergency, and in spite of the fact that the real successes of the Second New Deal had much less to do with growth than economic and social redistribution. ${ }^{43}$ As Klein cautions, a Green New Deal plan would fail dismally both in protecting the planet and in carrying out a just transition if it were to take the path of "climate Keynesianism." ${ }^{4}$

\section{The IPCC and Mitigation Strategies}

None of this is to deny that a tectonic shift appears to be underway. The radical Green New Deal strategies now being advocated threaten to blow apart the IPCC-led scientific-policy process with respect to what can and should be done to combat climate change, which has hitherto interdicted all left-social perspectives. In sharp contrast to its careful scientific treatment of the causes and consequences of climate change, which have been relatively free from political intervention, the IPCC's approach to the social actions necessary to mitigate the climate emergency has been dictated in large part by the current political-economic hegemony. Mitigation strategies for reducing carbon dioxide emissions worldwide have thus far been heavily impacted by the near total domination of capitalist relations of accumulation and the hegemony of neoclassical economics. The guidelines built into such mitigation scenarios heavily restrict the parameters of change under consideration via such devices as integrated assessment models (IAMs, large computer models that integrate energy markets and land use with greenhouse gas projections) and shared socioeconomic pathways (SSPs, consisting of five different business-as-usual pathways based on largely technological frameworks, with substantial economic growth and the lack of climate policy implementation formally built into all the models).

The result of such deliberately conservative models, which write off all alternatives to business as usual, is the proliferation of unrealistic assessments of both what can be done and what has to be done. ${ }^{45}$ In general, the mitigation scenarios incorporated into the IPCC process: (1) implicitly assume the need to perpetuate the current political-economic hegemony; (2) downplay changes in social relations in favor of technocratic change, much of it based on technologies that do not exist or are unfeasible; (3) stress supply-side, mainly price-related and technological factors, rather than demand-side factors, or direct reductions in ecological consumption so as to lower emissions; (5) rely on so-called negative emissions (capturing carbon dioxide from the atmosphere and somehow sequestering it) so as to allow 
the overshooting of emission targets; (6) leave the mass of the population out of account, assuming that change will be managed by managerial elites with minimal public participation; and (7) postulate slow responses, leaving out the possibility (indeed necessity) of ecological revolution. ${ }^{46}$

Hence, while the scale of climate change and its socioecological impacts are well captured by IPCC models and projections, the scale of the social change required to meet this challenge is systematically downgraded in the hundreds of mitigation models utilized by the IPCC. Magic bullets emanating from market-price interventions (such as carbon trading) and futuristic technology involving inventions that are not feasible on the necessary scale and that rely on negative emissions are resorted to instead. ${ }^{47}$ Such models point to catastrophic outcomes for which the only defenses are presumed to be so-called market efficiency and nonexistent and/or irrational baroque technology, since these approaches supposedly allow society to proceed with its current productive mode largely unaltered.

Thus, most climate mitigation models incorporate bioenergy with carbon capture and storage (BECCS) technology, which promotes growing plants (principally trees) on a massive scale to be burned to produce energy, while simultaneously capturing the carbon dioxide released into the atmosphere and somehow sequestering or storing it, as in geologic and ocean sequestration. If implemented, this would require a quantity of land equal to one or two Indias and an amount of freshwater approximating that which is currently used by world agriculture despite world water shortages..$^{48}$ Nor is the avid promotion of such purely mechanistic approaches an accident. It is deeply embedded in how these reports are constructed and the underlying capitalist order they serve.

In the words of leading climatologist Kevin Anderson of the Tyndall Centre for Climate Change Research in the United Kingdom:

The problem is that delivering on the $1.5-2^{\circ} \mathrm{C}$ commitment demands emissions cuts for wealthy nations of more than $10 \%$ each year, far beyond rates typically considered possible in the current economic system. It is in seeming to remedy this impasse that IAMs have an important and dangerous role. Behind a veneer of objectivity, the use of these leviathan computer models has professionalized the analysis of climate-change mitigation by substituting messy and contextual politics with non-contextual mathematical formalism. Within these professional boundaries, IAMs synthesize simple climate models, with a belief in how finance works and technologies change, buttressed by an [orthodox] economic interpretation of human behaviour...

Typically, IAMs use models based on free-market axioms. The algorithms embedded in these models assume marginal changes near economic equilibrium, and are heavily reliant on small variations in demand that 
result from marginal changes in prices. The Paris climate agreement, by contrast, sets a mitigation challenge that is far removed from the equilibrium of today's market economy, requiring immediate and radical change across all facets of society. ${ }^{49}$

The reality, Anderson stresses, is that current climate-scenario modeling and projections provided by the IPCC and incorporated into national plans are based on assumptions drawn from the general equilibrium analysis of neoclassical economics, building in notions of gradualist changes, based on the requirements of the profit system. Such stipulations in mitigation scenarios are meaningless in the context of the current climate emergency and dangerous in that they inhibit necessary action - so that nonexistent technology is seen as the only savior. Of the numerous models considered by the IPCC in its 2018 report, all require carbon dioxide reduction (CDR) or so-called negative emissions, mostly by technological means but also including afforestation..$^{50}$ The truth is that the whole mitigation approach within the IPCC, Anderson explains, has been an "accelerating failure," guiding a process that is radically opposed to its projections, with the result that "annual $\mathrm{CO}_{2}$ emissions have increased by about 70\% since 1990." Since the effects of such emissions are cumulative and nonlinear, with all sorts of positive feedbacks, the "ongoing failure to mitigate emissions has pushed the challenge from a moderate change in the economic system to a revolutionary overhaul of the system. This is not an ideological position; it emerges directly from a scientific and mathematical interpretation of the Paris climate agreement." ${ }^{51}$

Recognizing the accelerating climate emergency, the IPCC in its 2018 report departed from its previous reports in mildly encouraging the development of approaches to climate-change mitigation that include demand-side considerations. This means finding ways to reduce consumption, usually through increased efficiency (though typically downplaying the wellknown Jevons Paradox, where increasing efficiency under capitalism leads to increased accumulation and consumption)..$^{52}$ A number of mitigation scenarios have been introduced that demonstrate that demand-side interventions are the fastest way to address climate change - and even, in one model, suggesting that the below $-1.5^{\circ} \mathrm{C}$ target can be met with only slight overshoot and without reliance on so-called negative emission technologies, but rather depending on improved agricultural and forestry practices (considered a nontechnological form of carbon dioxide reduction). ${ }^{53}$ These results are achieved, moreover, within the extremely restrictive assumptions of the IPCC mitigation models, which formally build in (via IAMs and SSPs) significant rapid economic growth while formally excluding all climate policy (or political) interventions. It has therefore been suggested 
by some radical critics, such as Jason Hickel and Giorgos Kallis, that a demand-side sociopolitical approach that emphasizes abundance and redistributive policies, while placing limits on profits and growth (which today mainly benefit the .01 percent), is demonstratively far superior in mitigation terms and constitutes the only realistic solution. ${ }^{54}$

A major virtue of the rise of radical or people's Green New Deal strategies, therefore, is that they open up the realm of what is possible in accord with actual necessity, raising the question of transformative change as the only basis of human-civilizational survival: the freedom of necessity. ${ }^{55}$ Here it is important to recognize that an ecological and social revolution under present historical conditions is likely to pass through two stages that we can call ecodemocratic and ecosocialist. ${ }^{56}$ The self-mobilization of the population will initially take an ecodemocratic form, emphasizing the building of energy alternatives combined with a just transition, but in a context generally lacking any systematic critique of production or consumption. Eventually, however, the pressure of climate change and the struggle for social and ecological justice, spurred on by the mobilization of diverse communities, can be expected to lead to a more comprehensive ecorevolutionary view, penetrating the veil of the received ideology.

Still, the fact remains that the attempt to construct a radical Green New Deal in a world still dominated by monopoly-finance capital will be constantly threatened by a tendency to revert to Green Keynesianism, where the promise of unlimited jobs, rapid economic growth, and higher consumption militate against any solution to the planetary ecological crisis. As Klein remarks in On Fire,
Any credible Green New Deal needs a concrete plan for ensuring that the salaries from all the good green jobs it creates aren't immediately poured into high-consumer lifestyles that inadvertently end up increasing emis- sions - a scenario where everyone has a good job and lots of disposable income and it all gets spent on throwaway crap.... What we need are tran- sitions that recognize the hard limits on extraction and that simultaneous- ly create new opportunities for people to improve quality of life and derive pleasure outside the endless consumption cycle. ${ }^{57}$

The path toward ecological and social freedom requires abandoning a mode of production rooted in the exploitation of human labor and the expropriation of nature and peoples, leading to evermore frequent and severe economic and ecological crises. The overaccumulation of capital under the regime of monopoly-finance capital has made waste at every level integral to the preservation of the system, creating a society in which what is rational for capital is irrational for the world's people and the earth. ${ }^{58}$ This has led to the wasting away of human lives on unnecessary labor spent on producing 
useless commodities, requiring the squandering of the world's natural-material resources. Conversely, the extent of this profligate waste of human production and wealth, and of the earth itself, is a measure of the enormous potential that exists today for expanding human freedom and fulfilling individual and collective needs while securing a sustainable environment. ${ }^{59}$

In the current climate crisis, it is the imperialist countries at the center of the system that have produced the bulk of the carbon dioxide emissions now concentrated in the environment. It is these nations that still have the highest per capita emissions. These same states, moreover, monopolize the wealth and technology necessary to reduce global carbon emissions dramatically. It is therefore essential that the wealthy nations take on the larger burden for stabilizing the world's climate, reducing their carbon dioxide emissions at a rate of 10 percent or more a year. ${ }^{60}$ It is the recognition of this responsibility on the part of rich nations, together with the underlying global necessity, that has led to the sudden rise of transformative movements like Extinction Rebellion.

Over the longer run, however, the main impetus for worldwide ecological transformation will come from the Global South where the planetary crisis is having its harshest effects - on top of an already imperialist world system and a growing gap between rich and poor countries as a whole. It is in the periphery of the capitalist world that the legacy of revolution is the strongest - and the deepest conceptions of how to carry out such needed change persist. This is especially evident in countries such as Cuba, Venezuela, and Bolivia, which have sought to revolutionize their societies despite the harsh attacks by the imperialist world system and in spite of their historic dependence (in the cases of Venezuela and Bolivia) - itself imposed by the hegemonic structures of the global economy - on energy extraction. In general, we can expect the Global South to be the site of the most rapid growth of an environmental proletariat, arising from the degradation of material conditions of the population in ways that are equally ecological and economic. ${ }^{61}$

The role of China in all of this remains crucial and contradictory. It is one of the most polluted and resource-hungry countries in the world, while its carbon emissions are so massive as to themselves constitute a global-scale problem. Nevertheless, China has done more than any other country thus far to develop alternative-energy technologies geared to the creation of what is officially referred to as an ecological civilization. Remarkably, it remains largely self-sufficient in food due to its system of agriculture, in which the land is social property and agricultural production is mainly reliant on small producers with remnants of collective-communal responsibility. What is clear is that the present and future choices of the Chinese state, and even more the Chinese people, with 
respect to the creation of an ecological civilization are likely to be key in determining the long-term fate of the earth. ${ }^{62}$

Ecological revolution faces the enmity of the entire capitalist system. At a minimum it means going against the logic of capital. In its full development, it means transcending the system. Under these conditions, the reactionary response of the capitalist class backed by its rearguard on the far right will be regressive, destructive, and unrestrained. This can already be seen in the numerous attempts by Donald Trump's administration to remove the very possibility of making the changes necessary to combat climate change (seemingly in order to burn the world's ships behind it), beginning with its withdrawal from the Paris Climate Agreement and its acceleration of fossil fuel extraction. Ecological barbarism or ecofascism are palpable threats in the current global political context and are part of the reality with which any mass ecological revolt will need to contend. ${ }^{63}$ Only a genuine revolutionary, and not a reformist, struggle will be able to propel itself forward in these circumstances.

\section{An Age of Transformational Change}

It is commonplace in the social science literature, representing the reigning liberal ideology, to see society as simply constituted by the actions of the individuals that make it up. Other, more critical, thinkers sometimes present the opposite view that individuals are the product of the overall social structure. A third generic model sees individuals as affecting society and society affecting individuals in a kind of back and forth motion, viewed as a synthesis of structure and agency. ${ }^{64}$

In contrast to all of these mainstream, mostly liberal approaches, which leave little room for genuine social transformation, Marxian theory, with its historical-dialectical approach, relies on what the critical-realist philosopher Roy Bhaskar has called a "transformational model of social activity" in which individuals are historically born into and socialized in a given society (mode of production), which sets the initial parameters of their existence. ${ }^{65}$ However, these conditions and productive relations change in unpredictable, contingent ways during the course of their lives, leading to unintended consequences, contradictions, and crises. Caught in historical situations not of their choosing, human beings, acting both spontaneously and through organized social movements, reflecting class and other individual and collective identities, seek to alter the existing structures of social reproduction and social transformation, giving rise to critical historical moments consisting of radical breaks and revolutions, and new emergent realities. As Karl Marx wrote, "Men make their own history, but they do not make it just as they please; they do not make it 
under circumstances chosen by themselves, but under circumstances directly encountered, given and transmitted from the past." ${ }^{6}$

Such a transformational model of social activity supports a theory of human self-emancipation in history. Existing social relations become fetters on general human development; but they also give rise to fundamental contradictions in the labor and production process - or what Marx called the social metabolism of humanity and nature - leading to a period of crisis and transformation, threatening the revolutionary overturning of the social relations of production, or the relations of class, property, and power. ${ }^{67}$ Today we are presented with such severe contradictions in the metabolism of nature and society and in the social relations of production, but in a manner for which there is no true historical precedent.

In the Anthropocene, the planetary ecological emergency overlaps with the overaccumulation of capital and an intensified imperialist expropriation, creating an epochal economic and ecological crisis. ${ }^{68}$ It is the overaccumulation of capital that accelerates the global ecological crisis by propelling capital to find new ways to stimulate consumption to keep the profits flowing. The result is a state of planetary Armageddon, threatening not just socioeconomic stability, but the survival of human civilization and the human species itself. For Klein, the core explanation is simple: noting that "Marx wrote about capitalism's 'irreparable rift' with 'the natural laws of life itself," she goes on to underscore that "many on the left have argued that an economic system built on unleashing the voracious appetites of capital would overwhelm the natural systems on which life depended." ${ }^{69}$ And this is exactly what has happened in the period since the Second World War, through the great acceleration of economic activity, overconsumption on the part of the wealthy, and the resulting ecological destruction.

Capitalist society has long glorified the domination of nature. William James, the great pragmatist philosopher, famously referred in 1906 to "the moral equivalent of war." Though it is seldom mentioned, James's moral equivalent was a war on the earth, in which he proposed "to form for a certain number of years a part of the army enlisted against Nature."70 Today, we have to reverse this and create a new, more revolutionary moral equivalent of war; one directed not at the enlisting of an army to conquer the earth, but directed at the self-mobilization of the population to save the earth as a place of human habitation. This can only be accomplished through a struggle for ecological sustainability and substantive equality aimed at resurrecting the global commons. In the words of Thunberg speaking to the United Nations on September 23, 2019, "Right here, right now is where we draw the line. The world is waking up. And change is coming, whether you like it or not." The world is on fire this time. 


\section{Notes}

1. Here, revolution is viewed as a complex historical process, encompassing many actors and phases, sometimes nascent, sometimes developed, encompassing a fundamental challenging of the state along with the property, productive, and class structure of society. It may involve actors whose intentions are not revolutionary but who are objectively part of the development of a revolutionary situation. For a historical analogue, see George Lefebvre, The Coming of the French Revolution (Princeton: Princeton University Press, 1947). On the concept of ecological revolution itself, see John Bellamy Foster, The Ecological Revolution (New York: Monthly Review Press, 2009), 11-35.

2. Naomi Klein, On Fire: The (Burning) Case for a Green New Deal (New York: Simon and Schuster, 2019).

3. James Baldwin, The Fire Next Time (New York: Dial, 1963).

4. IPCC, Global Warming of $1.5^{\circ} \mathrm{C}$ (Geneva: IPCC, 2018).

5. John Haltiwanger, "This Is the Platform That Launched Alexandria Ocasio-Cortez, a 29-Year-Old Democratic Socialist, to Become the Youngest Woman Ever Elected to Congress," Business Insider, January 4, 2019.

6. Greta Thunberg, No One Is Too Small to Make a Difference (London: Penguin, 2019), 19-24.

7. Representative Alexandria Ocasio-Cortez, 116th Congress, 1st Session, House Resolution 109, "Recognizing the Duty of the Federal Government to Create a Green New Deal" (subsequently referred to as Green New Deal Resolution), February 7,2019, available at http://ocasio-cortez.house.gov.

8. Klein, On Fire, 1-7.

9. Thunberg, No One Is Too Small to Make a Difference, 61.

10. Bernie Sanders, "The Green New Deal," April 22, 2019, available at http:// berniesanders.com.

11. H. Res. 109, "Recognizing the Duty of the Federal Government to Create a Green New Deal," list of cosponsors available at http://congress.gov; S. Res. 59 , "Recognizing the Duty of the Federal Government to Create a Green New Deal," list of cosponsors available at http://congress.gov.

12. Eliza Barclay and Brian Resnick, "How Big Was the Global Climate Strike? 4 Million People Activists Estimate," Vox September 20, 2019.

13. "Transcript: Greta Thunberg's Speech to UN Climate Action Summit," NPR, September 23, 2019.

14. IPCC, Special Report on the Ocean and Cryosphere in a Changing Climate,
Summary for Policymakers (Geneva: IPCC, 2019), 22-24, 33.

15. Nicholas Stern, "We Must Reduce Greenhous Gas Emissions to Net Zero or Face More Floods," Guardian, October 7, 2018; "Transcript: Greta Thunberg's Speech to UN Climate Action Summit." Usually it is assumed that the world must stay below $2^{\circ} \mathrm{C}$ in order to avoid a point of no return with respect to the human relation to the planet. But more and more science has pointed to $1.5^{\circ} \mathrm{C}$ as the marker. Most IPCC-recognized climate mitigation schemes today assume a temporary overshooting of the $1.5^{\circ} \mathrm{C}$ boundary (or else the $2^{\circ} \mathrm{C}$ boundary) with negative emissions, then removing carbon from the atmosphere before the worst effects have occurred. But such a strategy, it is increasingly recognized, is worse than Russian roulette in terms of statistical odds-and more filled with illusions.

16. http://systemchangenotclimatt echange.org. See also Martin Empson, ed., System Change Not Climate Change (London: Bookmarks, 2019).

17. On the distinction between climate action and climate justice, see Klein, On Fire, 27-28.

18. The climate march was followed a few days later by the Flood Wall Street action, in which protestors engaged in civil disobedience but lacked the force of numbers.

19. Klein, On Fire, 27-28.

20. Thunberg, No One Is Too Small to Make a Difference, 16.

21. Green Party US, Green New Deal Timeline, available at http://gp.org; Green New Deal Policy Group, A Green New Deal (London: New Economics Foundation, 2008); Larry Elliott, "Climate Change Cannot Be Bargained With," Guardian, October 29, 2007.

22. Thomas Friedman, "A Warning from the Garden," New York Times, January 19, 2007.

23. Alexander C. Kaufman, "What's the 'Green New Deal'?" Grist, June 30, 2018.

24. UNEP, Global Green New Deal (Geneva: UNEP, 2009).

25. Green European Foundation, $A$ Green New Deal for Europe (Brussels: Green European Foundation, 2009).

26. David Milton, The Politics of U.S. Labor (New York: Monthly Review Press, 1982).

27. Climate Justice Alliance, "History of the Climate Justice Alliance."

28. John Bellamy Foster, "Ecosocialism and a Just Transition," MR Online, June 22, 2019; Climate Justice Alliance, "Just Transition: A Framework for Change."

29. Science for the People has been a leading defender of a Peoples' Green New Deal, incorporating a just transition for workers and frontline communities as opposed to attempts to fold the Green New Deal into its previous corporatist form. See Science for the People, "Peom ples' Green New Deal."

30. Jill Stein, "Solutions for a Country in Trouble: The Four Pillars of the Green New Deal," Green Pages, September 25, 2012. 31. Green Party, "We Can Build a Better Tomorrow Today, It's Time for a Green New Deal."

32. Tessa Stuart, "Sunrise Movement, the Force Behind the Green New Deal Ramps Up Plans for 2020," Rolling Stone, May 1, 2019. The founding Sunrise Movement activists had cut their teeth on the fossil-fuel disinvestment movement particularly in universities, which as of December 2018 claims to have succeeded in facilitating $\$ 8$ trillion in disinvestments. However, activists realized that the next step was to try to tackle the state itself and to change the system through a Green New Deal. Klein, On Fire, 22.

33. The Green Party has moved explicitly in the direction of ecosocialism and sponsored an ecosocialism conference in Chicago on September 28, 2019. See Anita Rios, "Green Party Gears Up for Ecosocialism Conference," Black Agenda Report, September 10, 2019.

34. H. Res. 109, "Recognizing the Duty of the Federal Government to Create a Green New Deal."

35. Sanders is entirely alone among the leading Democratic candidates in the 2020 elections in promoting a genuine Green New Deal. Joe Biden's "Plan for a Clean Energy Revolution and Environmental Justice," introduced in June 2019, avoids altogether the IPCC's insistence that carbon dioxide emissions have to be reduced by nearly 50 percent by 2030 in order to stay below $1.5^{\circ} \mathrm{C}$ and simply promises to promote policies that will achieve net-zero emissions by 2050 , proposing to spend $\$ 1.7$ trillion on combatting climate change over ten years. Elizabeth Warren has signed on to the Green New Dean Resolution, but in her "Clean Energy Plan," introduced in September 2019, she does not go beyond saying that she supports a tenyear mobilization through 2030 with the aim of reaching net-zero greenhouse gas emissions "as soon as possible." She proposes a $\$ 3$ trillion investment over ten years. Her plan excludes any mention of a just transition for workers or frontline communities.

36. Sanders, "The Green New Deal."

37. While the Green New Deal Resolution introduced by Ocasio-Cortez and Markey does not address how it would be 
financed, the emphasis has been on the creation of public banks, green quantitative easing, and deficit financing under current low capacity utilization-a view supported by modern monetary theory. It deliberately swerves away from funding by taxes on corporations. Ellen Brown, "The Secret to Funding a Green New Deal," Truthdig, March 19, 2019.

38. Historian David Blight, quoted in Ta-Nehisi Coates, "Slavery Made Ameri" ca," Atlantic, June 24, 2014

39. Ben Caldecott et al., Stranded Assets: A Climate Risk Challenge (Washington DC: Inter-American Development Bank, 2016): $x$.

40. Naomi Klein, This Changes Everything: Capitalism vs. the Climate (New York: Simon and Schuster, 2014), 31-63.

41. Klein, On Fire, 261; J. F. Mercure et al., "Macroeconomic Impact of Strands ed Fossil Fuel Assets," Nature Climate Change 8 (2018): 588-93.

42. Klein, This Changes Everything, 115-16.

43. Nancy E. Rose, Put to Work (New York: Monthly Review Press, 2009).

44. Klein, On Fire, 264.

45. Kevin Anderson, "Debating the Bedrock of Climate-Change Mitigation Scenarios," Nature, September 16, 2019; Zeke Hausfather, "Explainer: How 'Shared Socioeconomic Pathways' Explore Future Climate Change," Carbon Brief, April 19, 2018.

46. These shortcomings are built directly into the SSPs and even into the IAMs. See Oliver Fricko et al., "The Marker Quantifi: cation of the Shared Socioeconomic Pathway 2: A Middle-of-the-Road Scenario for the 21st Century," Global Environmental Change 42 (2017): 251-67. For a general critical evaluation, see Jason Hickel and Giorgos Kallis, "Is Green Growth Possible?" New Political Economy, April 17, 2019.

47. Kevin Anderson and Glen Peters, "The Trouble with Negative Emissions," Science 354, no. 6309 (2016): 182-83; European Academies Science Advisory Council, Negative Emission Technologies: What Role in Meeting Paris Agreement Targets, EASAC Policy Report 35 (Halle, Germany: German National Academy of Sciences, 2018).
48. See John Bellamy Foster, "Making War on the Planet," Monthly Review 70, no. 4 (September 2018): 4-6.

49. Anderson, "Debating the Bedrock of Climate-Change Mitigation Scenarios."

50. IPCC, Global Warming of $1.5^{\circ} \mathrm{C}, 16$, 96.

51. Anderson "Debating the Bedrock of Climate-Change Mitigation Scenarios."

52. See John Bellamy Foster, Brett Clark, and Richard York, The Ecological Rift (New York: Monthly Review Press, 2010), 169-82.

53. IPCC, Global Warming of $1.5^{\circ} \mathrm{C}$, 15-16, 97; Jason Hickel, "The Hope at the Heart of the Apocalyptic Climate Change Report," Foreign Policy, October 18, 2018. See also Arnulf Grubler, "A Low Energy Demand Scenario for Meeting the $1.5^{\circ} \mathrm{C}$ Target and Sustainable Development Goals Without Negative Emission Technologies," Nature Energy 3, no. 6 (2018): 512-27; Joeri Rogelj et al., "Scenarios Towards Limiting Global Mean Temperature Increase Below $1.5^{\circ} \mathrm{C}$," $\mathrm{Na}$ ture Climate Change 8 (2018): 325-32; Christopher Bertram et al. "Targeted Policies Can Compensate Most of the Increased Sustainability Risks in $1.5^{\circ} \mathrm{C}$ Mitigation Scenarios," Environmental Research Letters 13, no. 6 (2018).

54. Hickel and Kallis, "Is Green Growth Possible?"

55. J. D. Bernal, The Freedom of Necessity (London: Routledge and Kegan Paul, 1949).

56. See John Bellamy Foster, "Ecology," in The Marx Revival, ed. Marcelo Musto (Cambridge: Cambridge University Press, 2000), 193.

57. Klein, On Fire, 264.

58. See Paul A. Baran and Paul M. Sweezy, Monopoly Capital (New York: Monthly Review Press, 1966).

59. John Bellamy Foster, "The Ecology of Marxian Political Economy," Monthly Review 63, no. 4 (September 2011): 1-16; Fred Magdoff and John Bellamy Foster, What Every Environmentalist Needs to Know About Capitalism (New York: Monthly Review Press, 2011), 123-44; William Morris, News from Nowhere and Selected Writings and Designs (London: Penguin, 1962): 121-22.
60. Kevin Anderson and Alice Bows, "Beyond 'Dangerous' Climate Change: Emission Scenarios for a New World," Philosophical Transactions of the Royal Society 369 (2011): 20-44

61. For a discussion of the current ecological situation in the Global South and its relation to imperialism, see John Bellamy Foster, Hannah Holleman, and Brett Clark, "Imperialism in the Anthropon cene," Monthly Review 71, no. 3 (July-August 2019): 70-88. On the concept of the environmental proletariat, see Bellamy Foster, Clark, and York, The Ecological Rift, 440-41.

62. The issue of China and ecology is complex. See John B. Cobb (in conversation with Andre Vltchek), China and Ecological Civilization (Jakarta: Badak Merah, 2019); David Schwartzman, "China and the Prospects for a Global Ecological Civilization," Climate and Capitalism, September 17, 2019; Lau Kin Chi, "A Subaltern Perspective on China's Ecological Crisis," Monthly Review 70, no. 5 (October 2018): 45-57. On the concept of ecological civilization and its relation to China, see John Bellamy Foster, "The Earth-System Crisis and Ecological Civilization," International Critical Thought 7, no. 4 (2017): 439-58.

63. Naomi Klein, "Only a Green New Deal Can Douse the Fires of Ecofascism," Intercept, September 16, 2019.

64. Roy Bhaskar, Reclaiming Reality (London: Routledge, 2011), 74-76.

65. Bhaskar, Reclaiming Reality, 76-77, 92-94.

66. Karl Marx, Eighteenth Brumaire of Louis Bonaparte (1852; repr., New York: International Publishers, 1963): 15.

67. Karl Marx, Capital, vol. 1 (London: Penguin, 1976), 283

68. See lan Angus, Facing the Anthropocene (New York: Monthly Review Press, 2016), 175-91.

69. Klein, On Fire, 90-91; Karl Marx, Capital, vol. 3 (London: Penguin, 1981), 949

70. William James, "Proposing the MorP al Equivalent of War" (speech, Stanford University, 1906), available at Lapham's Quarterly online. 